\title{
ACSL3 Gene
}

National Cancer Institute

\section{Source}

National Cancer Institute. ACSL3 Gene. NCI Thesaurus. Code C97365.

This gene is involved in lipid biosynthesis. 